\title{
Health risk assessment and heavy metal contamination levels in vegetables from Tamale Metropolis, Ghana
}

\author{
Samuel Teye Ametepey ${ }^{1}$, Samuel Jerry Cobbina', Felix Jerry Akpabey², Abudu Ballu Duwiejuah ${ }^{1 *}$ (D \\ and Zita Naangmenyele Abuntori ${ }^{2}$
}

\begin{abstract}
Background: One major route of heavy metal exposure/ accumulation to humans is via vegetable consumption. The study assessed the levels of heavy metals and their associated health risk in frequently consumed vegetables in the Tamale Metropolis.

Results: Cadmium concentration in cabbage, carrot, green pepper, onion and tomato ranged from 0.04 to $0.07 \mathrm{mg} \mathrm{kg}^{-1}$, 0.01 to $0.06 \mathrm{mg} \mathrm{kg}^{-1}, 0.04$ to $0.06 \mathrm{mg} \mathrm{kg}^{-1}, 0.03$ to $0.06 \mathrm{mg} \mathrm{kg}^{-1}$ and 0.03 to $0.07 \mathrm{mg} \mathrm{kg}^{-1}$, respectively. Lead concentration in cabbage, carrot, green pepper and onion ranged from BDL to $0.03 \mathrm{mg} \mathrm{kg}^{-1}$, BDL to $0.02 \mathrm{mg} \mathrm{kg}^{-1}, \mathrm{BDL}$ to $0.04 \mathrm{mg} \mathrm{kg}^{-1}$, and $\mathrm{BDL}$ to $0.05 \mathrm{mg} \mathrm{kg}^{-1}$, respectively. The concentration of heavy metals in the various vegetables were below the World Health Organisation (WHO) standard.

Conclusions: The individual hazard index of vegetables for both children and adults were below 1 , indicating no potential risk to the public except for cadmium, chromium and manganese. The study also revealed that the hazard index of heavy metals studied were above 1, indicating non-acceptable level of non-carcinogenic adverse health effect.
\end{abstract}

Keywords: Consumption, Health risk assessment, Heavy metals, Vegetables

\section{Background}

Urban vegetable farming plays a vital role in city's nutritional needs as well as a source of income for farmers. Vegetable farming thrives on the availability of surface water, ground water or rain. The availability of fresh water for agricultural purpose has been a major constraint to urban vegetable farmers in the Tamale Metropolis and its surrounding communities. Due to unavailability of fresh water systems, some farmers resort to the use of waste water for cultivation of vegetables. About $40 \%$ of farmers have access to fresh water in the dry season (October to April) whilst about $50 \%$ have access to wastewater or grey water (Obuobie et al. 2006).

\footnotetext{
* Correspondence: abalu096@gmail.com

${ }^{1}$ Department of Ecotourism and Environmental Management, Faculty of Natural Resources and Environment, University for Development Studies, Nyankpala Campus, Tamale, Ghana

Full list of author information is available at the end of the article
}

Vegetables are essential for human nutrition and health, particularly as source of vitamin C, folic acid, minerals, niacin, thiamine, pyridoxine and dietary fiber, their biochemical role and their antioxidative effects (Siegel et al. 2014). One of the most essential aspects of food quality assurance is heavy metal contamination of the food items (Wang et al. 2005). There has been a growing concern about the safety of vegetables food produced in Tamale, as many farmers use waste water (Abubakari and Mahunu 2007).

Vegetables absorb metals from contaminated soils, besides from deposits on the parts of the vegetables exposed to polluted air (Haiyan and Stuanes 2003). Heavy metals can be readily adsorbed by vegetable roots, and can be accumulated in the edible parts of vegetables at high levels, regardless of the heavy metal concentration in the soil (Jolly et al. 2013). Anthropogenic activities are a major source of heavy metal contamination which includes agricultural crop residue, emission from industries 
and vehicular emissions. Generally, wastewater contains significant amounts of useful nutrients and heavy metals that create opportunities and problems in terms of agricultural production (Chen et al. 2005).

The consumption of vegetables contaminated with heavy metals may pose a risk to the health of humans. Heavy metals are deleterious due to their long biological half-lives, non-biodegradable nature, and their ability to accumulate in different body parts (Monu et al. 2008; Heidarieh et al. 2013). It is evident that prolonged consumption of foodstuff with unsafe concentrations of heavy metals may lead to chronic accumulation of heavy metals in the kidney and liver of human beings causing various disorders in numerous biochemical processes, leading to cardiovascular, bone, kidney and nervous diseases (Jarup 2003). The human health risk associated with consumption of vegetables depends on the quantity of vegetables consumed and the weight of the individual. Prolonged ingestion of heavy metals with low concentrations has a negative consequence on human health, and after several years of exposure the detrimental effect becomes apparent (Liu et al. 2005; Huang et al. 2007; Bortey-Sam et al. 2015).

Vegetable consumers are exposed to heavy metals via consumption and dermal contact in most countries and regions which can cause adverse health effects. Thus, contamination of heavy metals is of great concern in the environment and human health. The study determined the levels of some selected heavy metals concentration in vended vegetables and their associated human health risk in the Tamale Metropolis.

\section{Methods}

\section{Study area}

The study was conducted in the Central and Aboabo Markets within the Tamale, home to both locals and internationals. Tamale in Tamale Metropolis is the capital city of Northern Region (Fig. 1). Geographically, the Metropolis lies between latitude $9^{\circ} 16$ and $9^{\circ} 34$ North and longitudes $0^{\circ} 36$ and $0^{\circ} 57$ West (Ghana Statistical Service 2010). The Markets in Metropolis attract local goods from the agricultural and commerce sectors from the other Districts in the region. Also, gains from Markets in the West African Region from countries such as Burkina Faso, Niger, Mali and the northern part of Togo. There are 115 communities in the Metropolis. Most of the rural communities have a large expanse of land for agricultural activities and serve as the food basket for the Metropolis. There are four major Markets in the Metropolis namely: Central Market, Aboabo, Kukuo and Lamashegu Markets (Ghana Statistical Service 2010).

\section{Sampling and pretreatment}

Five selected vegetables (carrot, cabbage, green pepper, onion and tomato) were randomly bought from three vendors for two consecutive times in a month's interval. Six each of the five vegetables were collected making a total of 30 samples. The samples were transported to the laboratory for acid digestion. The edible portions vegetables were dried in the oven at $80{ }^{\circ} \mathrm{C}$ for $2-3$ days and weighed occasionally until a constant weigh was attained. The dried samples were then ground using mortar and pestle into a fine

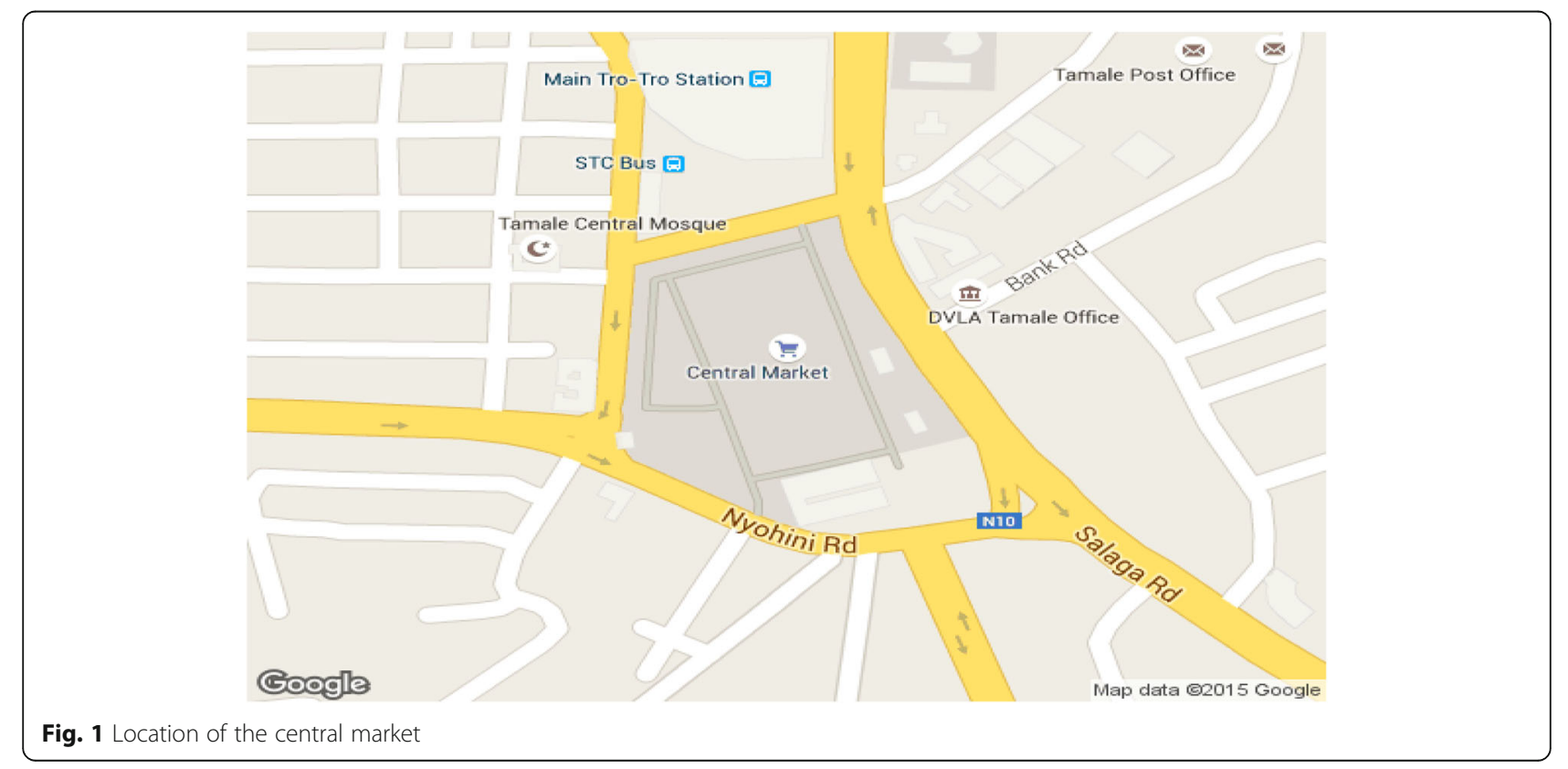


powder using a $2 \mathrm{~mm}$ sieve and stored in polyethylene bags, prior to acid digestion.

\section{Digestion and analysis}

Duplicates of each vegetable sample were weighed $(0.2 \mathrm{~g})$ into digestion flasks and treated with concentrated $10 \mathrm{ml} \mathrm{HNO}_{3}$ and $5 \mathrm{ml} \mathrm{H}_{2} \mathrm{SO}_{4}$. A blank sample was also prepared using $10 \mathrm{~mL}$ of $\mathrm{HNO}_{3}$ and $5 \mathrm{~mL}$ of $\mathrm{H}_{2} \mathrm{SO}_{4}$ into empty digestion flask (Sahito et al. 2002). The flasks were heated for $2 \mathrm{~h}$ on an electric hot plate (HP 220, UTEC Products Inc., and Albany N.Y., USA) at $80-90{ }^{\circ} \mathrm{C}$ before the temperature was raised to $150^{\circ} \mathrm{C}$ at which the samples were made to boil. Concentrated $\mathrm{HNO}_{3}$ and $\mathrm{H}_{2} \mathrm{SO}_{4}$ were further added to the sample $(3-5 \mathrm{~mL}$ of each was added occasionally) and digestion continued until a clear solution was obtained. The solution was allowed to cool and then filtered with Whatman's No. 42 filter paper and $<0.45 \mu \mathrm{m}$ Millipore filter paper. It was then transferred quantitatively to a $50 \mathrm{~mL}$ volumetric flask topped up to the mark with deionized water. The digested $50 \mathrm{~mL}$ filtrate solution was transferred into an acid rinsed polyethylene sample container with label for analysis. A Shimadzu, (AAS-6300), Atomic Absorption Spectrophotometer (AAS) was used for the determination of heavy metal concentration in the various vegetables. Results were reported in $\mathrm{mg} / \mathrm{kg}$ dry weight of sample.

\section{Quality control and assurance}

Strict quality assurance / quality control measures were taken to ensure reliability of the study results. All reagents and chemicals used were of good or high purity. Thoroughly glassware was cleaned with detergent and rinsed numerous times using deionised water before use. For quantification and detection limits of the Atomic Absorption Spectrophotometer purposes, a blank solution was read twenty five times, and the standard deviations were considered for the noise generation levels for each of the heavy metals. The LOD (detection limit) for each element was attained as follows: $\mathrm{LOD}=\frac{3 X S}{M}$.

Where $\mathbf{S}$ is the blank readings standard deviation and $\mathbf{M}$ is the gradient of the calibration curve for each metal. The quantification limit was considered using $10 \mathrm{~s} / \mathrm{m}$. The reproducibility and accuracy of the analytical procedure was done by spiking and homogenising 3 replicates of each of 3 samples selected. The triplicate of each sample was spiked with 3 diverse concentrations of the metal of interest as follows: $\mathrm{Cr}\left(1.0,2.0\right.$, and $\left.5 \mathrm{mg} \mathrm{l}^{-1}\right), \mathrm{Cd}(0.5,2.0$, and $\left.3.0 \mathrm{mg} \mathrm{l}^{-1}\right)$, Fe (2.0, 5.0, and $\left.10.0 \mathrm{mg} \mathrm{l}^{-1}\right), \mathrm{Pb}$ (2.0, 5.0, and $\left.10.0 \mathrm{mg} \mathrm{l}^{-1}\right)$ and $\mathrm{Zn}\left(0.25,0.5\right.$, and $\left.1.0 \mathrm{mg} \mathrm{l}^{-1}\right)$, and preserved in a manner similar as the samples. The absorbance measured by the atomic absorption spectrophotometer was converted to concentrations using standard calibration curves. $1000 \mathrm{mg} \mathrm{l}^{-1}$ single element standards of the metals of interest, found from Fluka Analytical (Sigma Aldrich Chemie $\mathrm{GmbH}$, Switzerland), were diluted using 10\% $\mathrm{HNO}_{3}$ and used to generate the calibration curves for the atomic absorption spectrophotometer analysis. The detection limit of Cd was $<0.002 \mathrm{mg} / \mathrm{kg}$, Cr was $<0.010 \mathrm{mg} / \mathrm{kg}, \mathrm{Pb}$ was $<0.050 \mathrm{mg} / \mathrm{kg}$, Mn was $<0.005$, Fe was $<0.010 \mathrm{mg} / \mathrm{kg}$, $\mathrm{Zn}$ was $<0.050 \mathrm{mg} / \mathrm{kg}$ and $\mathrm{Zn}$ was $<0.020 \mathrm{mg} / \mathrm{kg}$.

\section{Statistical analysis}

Means, standard deviations, minimum and maximum of the concentrations of the heavy metals for the various samples were calculated. Pearson's correlation was applied to examine specific relationships among the different metals. Pearson's correlation analysis was done to distinguish the possible common sources of heavy metals contamination and how some of the heavy metals influence their concentration.

\section{Health risk assessment}

To assess the potential health risks associated with long term ingestion of vegetables contaminated with heavy metals, the average daily dose (ADD) of heavy metals, hazard index (HI), target hazard quotient (THQ), and non-carcinogenic risk (NCR) were calculated. Table 1 shows the parameters that characterised the ADD.

$$
\mathrm{ADD}=\frac{\mathrm{Ci} \times \mathrm{IR} \times \mathrm{EF} \times \mathrm{ED}}{\mathrm{BW} \times \mathrm{AT}}
$$

Where $\mathrm{Ci}$ is metal concentration in the vegetable, IR is ingestion rate, $\mathrm{EF}$ is exposure frequency, $\mathrm{ED}$ is exposure duration, BW is body weight of consumer and AT is average time. The health risk was assessed in relation to its non-carcinogenic as well as carcinogenic effects based on the calculation of ADD estimates and defined toxicity according to the following relationships (USEPA IRIS 2011; Wongsasuluk et al. 2014).

Estimation of non-carcinogenic risk of heavy metals consumption was determined using target hazard quotient

Table 1 Input parameters to characterise the ADD Value (Wongsasuluk et al. 2014)

\begin{tabular}{llll}
\hline Exposure parameters & Symbols & Units & Value \\
\hline Concentration & $\mathrm{C}$ & $\mathrm{mg} / \mathrm{kg}$ & - \\
Ingestion rate & $\mathrm{IR}$ & $\mathrm{g} / \mathrm{day}$ & 2.2 \\
Exposure frequency & $\mathrm{EF}$ & days/year & 365 \\
Exposure duration & $\mathrm{ED}$ & years & 70 \\
Adult BW & $\mathrm{BW}$ & $\mathrm{kg}$ & 70 \\
Child BW & $\mathrm{BW}$ & $\mathrm{kg}$ & 16 \\
Average time & AT & years & 25,550 days \\
\hline
\end{tabular}


values. Target hazard quotient is a ratio of the determined dose of a contaminant to oral reference dose considered detrimental. If the ratio is greater than or equal to 1 , an exposed population is at risk. The non-carcinogenic was computed as (Eq. 2):

$$
\text { Hazard Quotients }(\mathrm{HQ})=\frac{\mathrm{ADD}}{\mathrm{RfD}}
$$

Where ADD is average daily dose and RfD is reference dose.

Hazard index is used to estimate the potential human health risk when more than one heavy metal is consumer. HI was calculated as the sum of HQs.

$$
\text { HI }=(\text { THQi }+ \text { THQii }+ \text { THQiii.........THQn }) \Sigma T H Q
$$

The individual metal toxicity responses (dose response) are $5.0 \times 10^{-4}$ for $\mathrm{Cd}, 3.0 \times 10^{-3}$ for $\mathrm{Cr}, 3.5 \times 10^{-3}$ for $\mathrm{Pb}$, $1.4 \times 10^{-2}$ for $\mathrm{Mn}, 7.0 \times 10^{-1}$ for $\mathrm{Fe}, 3.0 \times 10^{-1}$ for $\mathrm{Zn}$, and $4.2 \times 10^{-2}$ for $\mathrm{Cu}$ all in $\mathrm{mg} / \mathrm{kg} /$ day as the Oral Reference Dose (RfD) (USEPA IRIS 2011; Wongsasuluk et al. 2014). The risk assessments of a mixture of chemicals, the individual $\mathrm{HQs}$ are summed to form hazard index $(\mathrm{HI})$ : According to Lim et al. (2008) an HI / HQ > 1 means an unacceptable risk of non-carcinogenic effects on health, whilst HI / HQ $<1$ means an acceptable level of risk.

\section{Results and discussion}

\section{Heavy metals concentrations in vegetables}

The Cd concentration in cabbage, carrot, green pepper, onion and tomato are presented in Table 2. The study revealed that cadmium concentration in the five vegetables were below the WHO / FAO stipulate limit of $0.02 \mathrm{mg} \mathrm{kg}^{-1}$ (WHO / FAO 2007). In Ghana, a study conducted by Lente et al. (2012) reported cadmium values below detection limit of $0.006 \mathrm{mg} \mathrm{kg}^{-1}$ in vegetables grown in long-term wastewater irrigated urban farming sites in Accra. Similar study conducted by Odai et al. (2008) on vegetables grown on waste dumping sites in Kumasi, reported high cadmium levels that ranged from 0.68 to $1.78 \mathrm{mg} \mathrm{kg}^{-1}$. Previous studies conducted in the Varanasi, Harare and Addis Ababa, also reported elevated concentration of cadmium that was estimate to be 1 to 5 times higher than the maximum reference limit (MRL) (Mapanda et al. 2007; Sharma et al. 2007; Weldegebriel et al. 2012). Also, Muchuweti et al. (2006) who studied local vegetables Tsunga leaves irrigated with wastewater in Harare reported Cd concentration of $3.68 \mathrm{mg} \mathrm{kg}^{-1}$ that is 18 times over EU standards. It is obvious that cadmium is becoming an increasing health concern in wastewater irrigated agriculture as it's associated with damage of kidneys, bones and its probable carcinogenic nature (Suruchi and Pankaj 2011). Also, cadmium is dangerous
Table 2 Heavy metal concentrations of the vegetables

\begin{tabular}{|c|c|c|c|c|c|c|c|c|}
\hline Vegetables & Results & $\mathrm{Cd}$ & $\mathrm{Cr}$ & $\mathrm{Pb}$ & $\mathrm{Mn}$ & $\mathrm{Fe}$ & $\mathrm{Zn}$ & $\mathrm{Cu}$ \\
\hline \multirow[t]{4}{*}{ Cabbage } & Min. & 0.04 & 0.03 & $\mathrm{BDL}$ & 0.10 & 3.23 & 0.06 & 0.04 \\
\hline & Max. & 0.07 & 0.47 & $\mathrm{BDL}$ & 0.26 & 3.97 & 0.16 & 0.07 \\
\hline & Mean & 0.05 & 0.35 & $\mathrm{BDL}$ & 0.16 & 3.57 & 0.09 & 0.06 \\
\hline & SD & 0.01 & 0.16 & $\mathrm{BDL}$ & 0.06 & 0.27 & 0.04 & 0.01 \\
\hline \multirow[t]{4}{*}{ Carrot } & Min. & 0.01 & 0.25 & $\mathrm{BDL}$ & 0.11 & 3.75 & 0.07 & 0.05 \\
\hline & Max. & 0.06 & 0.64 & 0.02 & 0.95 & 4.37 & 0.25 & 0.09 \\
\hline & Mean & 0.04 & 0.40 & $\mathrm{BDL}$ & 0.30 & 4.06 & 0.12 & 0.07 \\
\hline & SD & 0.02 & 0.13 & 0.03 & 0.33 & 0.22 & 0.07 & 0.01 \\
\hline \multirow[t]{4}{*}{ Green pepper } & Min. & 0.04 & 0.15 & $\mathrm{BDL}$ & 0.06 & 3.20 & 0.05 & 0.07 \\
\hline & Max. & 0.06 & 0.54 & 0.04 & 0.21 & 4.47 & 0.10 & 0.09 \\
\hline & Mean & 0.05 & 0.34 & $\mathrm{BDL}$ & 0.13 & 3.74 & 0.07 & 0.08 \\
\hline & SD & 0.01 & 0.15 & 0.05 & 0.05 & 0.51 & 0.02 & 0.01 \\
\hline \multirow[t]{4}{*}{ Onion } & Min. & 0.03 & 0.13 & $\mathrm{BDL}$ & 0.07 & 3.22 & 0.05 & 0.04 \\
\hline & Max. & 0.06 & 0.52 & $\mathrm{BDL}$ & 0.15 & 4.40 & 0.12 & 0.07 \\
\hline & Mean & 0.05 & 0.32 & $\mathrm{BDL}$ & 0.11 & 3.76 & 0.08 & 0.06 \\
\hline & SD & 0.01 & 0.15 & $\mathrm{BDL}$ & 0.03 & 0.44 & 0.03 & 0.01 \\
\hline \multirow[t]{4}{*}{ Tomatoes } & Min. & 0.03 & 0.07 & $\mathrm{BDL}$ & 0.06 & 3.04 & 0.06 & 0.05 \\
\hline & Max. & 0.07 & 0.60 & $\mathrm{BDL}$ & 0.39 & 4.10 & 0.09 & 0.07 \\
\hline & Mean & 0.05 & 0.35 & $\mathrm{BDL}$ & 0.14 & 3.42 & 0.08 & 0.06 \\
\hline & SD & 0.01 & 0.20 & $\mathrm{BDL}$ & 0.12 & 0.38 & 0.01 & 0.01 \\
\hline \multicolumn{2}{|c|}{ WHO/FAO ( 2007) } & 0.02 & 5 & 0.30 & 500 & 450 & 60 & 40 \\
\hline
\end{tabular}
collected from the Tamale Market

BDL: Below Detectable Limit, All mean concentrations are in $\mathrm{mg} \mathrm{kg}^{-1}$

because it can be taken up through the alimentary tract; penetrate through placenta during pregnancy, and damage membranes and the DNA. Once in the human body, it may persist in the metabolism from 16 to 33 years, and is connected to numerous health problems that include renal damages and abnormal urinary excretion of proteins (Guerra et al. 2012). The decrease in bone calcium concentration and increase of urinary excretion of calcium has also been linked to $\mathrm{Cd}$ exposure that can cause death (WHO 2004).

Chromium concentration in cabbage, carrot, green pepper, onion and tomato are presented in Table 2. Generally, the chromium concentrations in the five vegetables were below the WHO / FAO stipulated limit of $5.0 \mathrm{mg} \mathrm{kg}^{-1}$ (WHO / FAO 2007). The study revealed that $\mathrm{Cr}$ level in the various vegetables might not pose health risk to consumers. Chromium is crucial for insulin activity and deoxyribonucleic acid transcription in living organism particularly human beings. However, an intake less than $0.02 \mathrm{mg}$ per day could lessen cellular responses to insulin (Kohlmeier 2003). Hence, the concentrations of $\mathrm{Cr}$ in the vegetables are suitable for proper cellular response to insulin. A study conducted by Lente et al. (2012) reported $\mathrm{Cr}$ values below detection limit of $0.002 \mathrm{mg} \mathrm{kg}^{-1}$ in 
vegetables grown in long-term wastewater irrigated urban farming sites in Accra. A similar study in China reported $\mathrm{Cr}$ concentration of $0.546 \mathrm{mg} \mathrm{kg}^{-1}$ in vegetables (Suruchi and Pankaj 2011) that is also low as obtained in this study.

Lead has toxic effects on organs that include kidneys, liver, lung and spleen that cause different biochemical defects. It exhibits neuropathology when adults are exposed occupationally or accidentally to excessive levels. There is a relationship between $\mathrm{Pb}$ in the human body and the increase of blood pressure of adults (Maihara and Fávaro 2006). $\mathrm{Pb}$ concentration in cabbage, carrot, green pepper, onion and tomato are presented in Table 2. The present study revealed that the lead concentration in five vegetables were below the WHO / FAO stipulated limit of $0.30 \mathrm{mg} \mathrm{kg}^{-1}$ (WHO / FAO 2007). Similar studies conducted in Ghana reported concentration of $\mathrm{Pb}$ with mean range of 5.59 to $10.51 \mathrm{mg} \mathrm{kg}^{-1}$ in vegetables grown in long-term wastewater irrigated urban farming sites in Accra (Lente et al. 2012) and in Kumasi Odai et al. (2008) reported $\mathrm{Pb}$ concentration that ranged from 2.42 to $13.50 \mathrm{mg} \mathrm{kg}^{-1}$. In China, Suruchi and Pankaj (2011) reported $2.652 \mathrm{mg} \mathrm{kg}^{-1}$ of $\mathrm{Pb}$ in vegetables.

The study obtained manganese concentration in cabbage, carrot, green pepper, onion and tomato are presented in Table 2. Mn concentration of the vegetables were within WHO/FAO stipulated limit of $500 \mathrm{mg} \mathrm{kg}^{-1}$ (WHO / FAO 2007).

Iron concentration in cabbage, carrot, green pepper, onion and tomato are presented in Table 2. Iron level in the five vegetables were below the WHO / FAO stipulated limit of $450 \mathrm{mg} \mathrm{kg}^{-1}$ (WHO / FAO 2007). Similarly, a study in India reported Fe concentration that ranged from 116 to $378 \mathrm{mg} \mathrm{kg}{ }^{-1}$ in vegetables obtained wastewater-irrigated farms (Monu et al. 2008). In human, excess ingestion of Fe can result in deposition of iron in tissues (siderosis) in adrenals, liver, pancreas, thyroid, pituitary among others (Codex 2011).

Zinc concentration in cabbage, carrot, green pepper, onion and tomato are presented in Table 2. Zinc level in the five vegetables were below the WHO / FAO stipulate limit of $60 \mathrm{mg} \mathrm{kg}^{-1}$ (WHO/FAO 2007). In Ghana, a study conducted by Lente et al. (2012) reported $\mathrm{Zn}$ values below $10 \mathrm{mg} \mathrm{kg}^{-1}$ in vegetables grown in long-term wastewater irrigated urban farming sites in Accra. Similar studies conducted by Singh et al. (2010) showed elevated levels of $\mathrm{Zn}$ in Varanasi whilst that of Sharma et al. (2007) showed that the $\mathrm{Zn}$ was within the MRL.

Zinc is an essential mineral due to its exceptional biologic and public health significance (Hambidge and Krebs 2007) but excessive ingestion can have adverse effects on human health (Rahman et al. 2014). Zn can reduce immune function and the levels of high-density lipoproteins (Harmanescu et al. 2011). In the developing world, its deficiency affects about two billion people and is related with many diseases (Prasad 2003). It causes growth retardation, delayed sexual maturation, infection susceptibility, and diarrhoea in children. It is responsible for about 800,000 children death worldwide per year (Hambidge and Krebs 2007).

Copper concentration in cabbage, carrot, green pepper, onion and tomato are presented in Table 2. Copper level in the five vegetables were above the WHO / FAO stipulate limit of $40 \mathrm{mg} \mathrm{kg}^{-1}$ (WHO / FAO 2007). This suggests that $\mathrm{Cu}$ concentration in the various vegetables is unsafe for consumption. In Ghana, a study conducted by Lente et al. (2012) reported $\mathrm{Cu}$ values below $10 \mathrm{mg} \mathrm{kg}^{-1}$ in vegetables grown in long-term wastewater irrigated urban farming sites in Accra. Copper is essential for humans as a trace dietary mineral. However, excessive consumption of $\mathrm{Cu}$ can lead to adverse effects on human health (Rahman et al. 2014). For instance, a $\mathrm{Cu}$ excess can cause acute intestine and stomach aches, and liver damage (Rahman et al. 2014). Similar studies conducted in Varanasi by Singh et al. (2010) recorded elevated concentration of $\mathrm{Cu}$.

\section{Correlation matrix of the parameters}

Bivariate correlation analysis was carried out to ascertain the degree of interrelation and association of the two of the heavy metals. Iron correlated positively $\mathrm{Pb}, \mathrm{Cr}$ and $\mathrm{Cu}, \mathrm{Pb}$ correlated positively $\mathrm{Cu}$, and $\mathrm{Cd}$ correlated negatively with Mn (Table 3). It demonstrated that the metals that shows positively mutual associations commonly interacts and their source of pollution common, whilst the negatively correlated shows vice versa.

\section{Health risk assessment}

The exposure routes to the target organisms are used to detect the health risk of any pollutant as it is very essential to estimate exposure level. There are many pathways of heavy metals exposure to humans. Ingestion of vegetables contaminated with significant amounts of heavy metal could cause harm to the human health. The human health risk associated with the average daily dose was determined manually using the mean concentrations of $\mathrm{Cd}, \mathrm{Cr}, \mathrm{Pb}, \mathrm{Mn}, \mathrm{Fe}, \mathrm{Zn}$ and $\mathrm{Cu}$ in the various

Table 3 Correlation matrix of heavy metal in the vegetables

\begin{tabular}{llllllll}
\hline Metal & $\mathrm{Cd}$ & $\mathrm{Cr}$ & $\mathrm{Pb}$ & $\mathrm{Mn}$ & $\mathrm{Fe}$ & $\mathrm{Zn}$ & $\mathrm{Cu}$ \\
\hline $\mathrm{Cd}$ & 1 & 0.23 & 0.18 & $-0.45^{\mathrm{a}}$ & 0.17 & -0.05 & 0.11 \\
$\mathrm{Cr}$ & & 1 & 0.33 & -0.01 & $0.46^{\mathrm{a}}$ & 0.08 & 0.27 \\
$\mathrm{~Pb}$ & & & 1 & 0.07 & $0.53^{\mathrm{b}}$ & 0.08 & $0.54^{\mathrm{b}}$ \\
$\mathrm{Mn}$ & & & & 1 & 0.11 & 0.01 & -0.15 \\
$\mathrm{Fe}$ & & & & & 1 & 0.20 & $0.42^{\mathrm{a}}$ \\
$\mathrm{Zn}$ & & & & & & 1 & 0.06 \\
$\mathrm{Cu}$ & & & & & & & 1 \\
\hline
\end{tabular}

${ }^{a}$ Correlation is significant at the 0.05 level (2-tailed)

${ }^{\mathrm{b}}$ Correlation is significant at the 0.01 level (2-tailed) 
vegetables and their results are presented in Table 4 . The ADD values for adult and child are presented in Table 4. It is evident that HQs were all less than 1 for all vegetables for both adults and children. Hence, there is no need for concern regarding the continuous consumption of the vegetables in terms of potential health risk. When HQ exceeds 1 , there is concern for potential health effect (Huang et al. 2008).

The study showed HQ to be less than 1 suggesting an acceptable level of non-carcinogenic adverse health risk except for $\mathrm{Cd}, \mathrm{Cr}$ and $\mathrm{Mn}$ (Table 5). In adult, $\mathrm{Cd}$ and $\mathrm{Cr}$ ranged from 2.54 to $3.14,3.33$ to 3.67 , respectively whilst in children, $\mathrm{Cd}$ recorded constant value of 11.00 and $\mathrm{Cr}$ and $\mathrm{Mn}$ ranged from 1.83 to 16.00 and 1.08 to 2.95 , respectively (Table 5 ).

Hazard index (HI) values of the heavy metals studied ranged from 6.51 to 29.30 that were above 1, indicating non-acceptable level of non-carcinogenic adverse health effect. Hence, HI recorded in Tamale Market indicates the contribution of heavy metals can lead to aggregate risk via consumption of vegetables. This high HI values for all heavy metals observed in cabbage, green pepper, onion and tomato have great potential to pose health risk to the consumer. The difference in THQ values for adults and children are usually attributable to the differences in the ingestion of the heavy metals, body weight between adults and children, and exposure time. Similar, studies conducted by Harmanescu et al. (2011) and Zhou et al. (2016) observed differences HI (THQ) values in males and females through vegetable consumption in Banat Country in Romania, Shizhuyuan area in China, respectively.

Table 4 Average Daily Dose (ADD) (mg/kg-day) for selected vegetables

\begin{tabular}{lllllll}
\hline Metal & & Cabbage & Carrot & Green pepper & Onion & Tomato \\
\hline $\mathrm{Cd}$ & Adult & - & - & - & - & - \\
$\mathrm{Cd}$ & Child & 0.01 & 0.01 & 0.01 & 0.01 & 0.01 \\
$\mathrm{Cr}$ & Adult & 0.01 & 0 & 0.01 & 0.01 & 0.01 \\
$\mathrm{Cr}$ & Child & 0.04 & 0.01 & 0 & 0.04 & 0 \\
$\mathrm{~Pb}$ & Adult & - & - & - & - & - \\
$\mathrm{Pb}$ & Child & - & - & - & - & - \\
$\mathrm{Mn}$ & Adult & 0.01 & 0.01 & - & - & - \\
$\mathrm{Mn}$ & Child & 0.02 & 0.04 & 0.01 & 0.02 & 0.02 \\
$\mathrm{Fe}$ & Adult & 0.07 & 0.13 & 0.12 & 0.12 & 0.11 \\
$\mathrm{Fe}$ & Child & 0.29 & 0.56 & 0.51 & 0.52 & 0.47 \\
$\mathrm{Zn}$ & Adult & - & - & - & - & - \\
$\mathrm{Zn}$ & Child & 0.01 & 0.02 & 0.01 & 0.01 & 0.01 \\
$\mathrm{Cu}$ & Adult & - & - & - & - & - \\
$\mathrm{Cu}$ & Child & 0.01 & 0.01 & 0.01 & 0.01 & 0.01 \\
\hline
\end{tabular}

Table 5 Non-carcinogenic risk (hazard quotient, HQ) and overall toxic risk (hazard index, $\mathrm{HI}$ ) of various vegetables in Tamale Metropolis

\begin{tabular}{lllllllll}
\hline Vegetables & $\mathrm{Cd}$ & $\mathrm{Cr}$ & $\mathrm{Pb}$ & $\mathrm{Mn}$ & $\mathrm{Fe}$ & $\mathrm{Zn}$ & $\mathrm{Cu}$ & $\mathrm{HI}$ \\
\hline Adult & & & & & & & & \\
$\quad$ Cabbage & 2.54 & 3.33 & 0.14 & 0.36 & 0.1 & 0.01 & 0.03 & 6.51 \\
Carrot & 2.51 & 0.42 & - & 0.67 & 0.18 & 0.01 & 0.06 & 3.85 \\
Green pepper & 3.14 & 3.57 & - & 0.29 & 0.17 & 0.01 & 0.06 & 7.24 \\
Onion & 3.14 & 3.33 & - & 0.25 & 0.17 & 0.01 & 0.21 & 7.11 \\
$\quad$ Tomato & 3.14 & 3.67 & - & 0.31 & 0.15 & 0.01 & 0.21 & 7.49 \\
Child & & & & & & & & \\
Cabbage & 11 & 14.67 & 0.14 & 1.57 & 0.42 & 0.05 & 0.14 & 27.99 \\
Carrot & 11 & 1.83 & - & 2.95 & 0.8 & 0.06 & 0.25 & 16.89 \\
Green pepper & 11 & 15.58 & - & 1.28 & 0.74 & 0.03 & 0.28 & 28.91 \\
Onion & 11 & 14.67 & - & 1.08 & 0.74 & 0.04 & 0.21 & 27.74 \\
Tomato & 11 & 16 & - & 1.38 & 0.67 & 0.04 & 0.21 & 29.30 \\
\hline
\end{tabular}

The consequence can be more severe for special populations (people with weak constitution, sensitive, and pregnant women) the potential human health risks of heavy metal accumulation through vegetable consumption. Though, vegetable intake is just a proportion of food consumed, supplementary or complementary food that may include fish (Wang et al. 2005), meat (Zheng et al. 2007; Bortey-Sam et al. 2015; Barone et al. 2015), rice (Zheng et al. 2007; Hang et al. 2009), and tobacco (Dong et al. 2015) that are consumed can also contribute and/ increase amounts of heavy metals.

\section{Conclusion}

The present study was performed to assess heavy metal levels of commonly consumed vegetables and their associated health risks in the Tamale Metropolis. Generally, the heavy metals concentrations in the various vegetables are all below the permissible limit of WHO / FAO. The individual hazard quotient values were all below 1 except $\mathrm{Cd}$ and $\mathrm{Cr}$ in adult and $\mathrm{Cd}, \mathrm{Cr}$ and $\mathrm{Mn}$ in children that suggest an acceptable level of non-carcinogenic adverse risk. The hazard index for both adult and children exceeded 1 which may pose future risk such as cancer. Based on the findings of this study; it is recommended that further research work should be carried out to study the levels of heavy metals in vegetables in and around Tamale in order to maintain and/ or improve measures to reduce their levels in vegetables and ultimately prevent these avoidable health problems.

\footnotetext{
Acknowledgements

The authors are sincerely grateful to all Staff of CSIR-Water Research Institute, Tamale especially Mr. Abdul-Latif Salifu for their vital contribution to the research work. We are equally expressing our profound gratitude to management of CSIR-Savanna Agriculture Research Institute, Nyankpala for helping in the acid digestion.
} 


\section{Funding}

The authors self-funded study from data collection, analysis and interpretation and to the final writing of the manuscript.

\section{Availability of data and materials}

The data used in the presented work has been purchased and has been used freely available. All the data has been used in the present work.

\section{Authors' contributions}

TSA and SJC have contributed in the study conception and design, data acquisition, and analysis and interpretation of data. TSA, SJC, FJA, ABD and ZNA participated in the intellectual helping in different stages of the study. TSA, ABD and ZNA participated in drafting of manuscript and preparation of final version. All Authors have read the manuscript and have agreed to submit it in its current form for consideration for publication. All authors read and approved the final manuscript.

\section{Ethics approval and consent to participate}

There is no any ethical conflict.

\section{Competing interests}

The authors declare that they have no competing interests.

\section{Author details}

'Department of Ecotourism and Environmental Management, Faculty of Natural Resources and Environment, University for Development Studies, Nyankpala Campus, Tamale, Ghana. ${ }^{2}$ Environmental Chemistry Division, CSIR-Water Research Institute, Tamale, Ghana.

\section{Received: 8 February 2018 Accepted: 5 June 2018}

Published online: 14 June 2018

\section{References}

Abubakari AH, Mahunu G. The role of urban horticulture in urban development a case study of the tamale metropolis. Ghana J Horticulture. 2007;6:129-33.

Barone G, Storelli A, Garofalo R, Busco VP, Quaglia NC, Centrone G, Storelli MM. Assessment of mercury and cadmium via seafood consumption in Italy: estimated dietary intake (EWI) and target hazard quotient (THQ). Food Addit Contam A. 2015:32:1277-86.

Bortey-Sam N, Nakayama SMM, Ikenaka Y, Akoto O, Baidoo E, Yohannes YB, Mizukawa $\mathrm{H}$, Ishizuka M. Human health risks from metals and metalloid via consumption of food animals near gold mines in Tarkwa, Ghana: estimation of the daily intakes and target hazard quotients (THQs). Ecotoxicol Environ Saf. 2015:111:160-7.

Chen Y, Wang C, Wang Z. Residues and source identification of persistent organic pollutants in farmland soils irrigated by effluents from biological treatment plants. Environ Int. 2005;31:778-83.

Codex Alimentarius Commission (2011) Joint FAO/WHO Food Standards Programme Codex Committee on Contaminants in Foods Fifth Session: Working Document.

Dong Z, Bank MS, Spengler JD. Assessing metal exposures in a community near a cement plant in the Northeast US. Int J Environ Res Public Health. 2015:12:952-69.

Ghana Statistical Service (GSS) (2010) Population and housing census.

Guerra F, Trevizam AR, Muraoka T, Marcante NC, Canniatti-Brazaca SC. Heavy metals in vegetables and potential risk for human health. Sci Agric. 2012;69(1):54-60

Haiyan W, Stuanes AO. Heavy metal pollution in air-water-soil-plant. Water Air Soil Pollut. 2003;147:79-107.

Hambidge KM, Krebs NF. Zinc deficiency: a special challenge. J Nutr. 2007;137(4):1101-15

Hang X, Wang H, Zhou J, Ma C, Du C, Chen X. Risk assessment of potentially toxic element pollution in soils and rice (Oryza sativa) in a typical area of the Yangtze River Delta. Environ Pollut. 2009;157:2542-9.

Harmanescu M, Alda LM, Bordean DM, Gogoasa L, Gergen L. Heavy metals health risk assessment for population via consumption of vegetables grown in old mining area, a case study: Banat County, Romania. Chem Cent J. 2011;5:64-73.

Heidarieh M, Maragheh MG, Shamami MA, Behgar M, Ziaei F, Akbari Z. Evaluate of heavy metal concentration in shrimp (Penaeus semisulcatus) and crab (Portunus pelagicus) with INAA method. Springer Plus. 2013;2:72.

Huang ML, Zhou SL, Sun B, Zhao QG. Heavy metals in vegetables: assessment of potential health risk for inhabitants in Khunshan China. Sci Tota Env. 2008:405:54-61.
Huang SS, Liao QL, Hua M, Wu XM, Bi KS, Yan CY, Chen B, Zhang XY. Survey of heavy metal pollution and assessment of agricultural soil in Yangzhong district, Jiangsu Province, China. Chemosphere. 2007;67:2148-55.

Jarup L. Hazards of heavy metal contamination. Br Med Bull. 2003:68:167-82.

Jolly YN, Islam A, Akbar S. Transfer of metals from soil to vegetables and possible health risk assessment. Springer Plus. 2013;2:385-91.

Kohlmeier M. Nutrient metabolism. San Diego: Elsevier; 2003.

Lente I, Keraita B, Drechsel P, Ofosu-Anim J, Brima AK. Risk assessment of heavymetal contamination on vegetables grown in long-term wastewater irrigated urban farming sites in Accra, Ghana. Water Qual Expo Health. 2012;4:179-86.

Lim HS, Lee JS, Chon HT, Sager M. Heavy metal contamination and health risk assessment in the vicinity of the abandoned Songcheon au-ag mine in Korea. J Geochem Explor. 2008;96:223-30.

Liu H, Probst A, Liao B. Metal contamination of soils and crops affected by the Chenzhou lead/zinc mine spill (Hunan, China). Sci Total Environ. 2005:339:153-66.

Maihara VA, Fávaro DIT. Toxic Elements. p. 629-660. In: Cozzolino SMF, editor. Bioavailability of nutrients. Barueri: Manole; 2006. (in Portuquese).

Mapanda F, Mangwayana EN, Nyamangara J, Giller KE. Uptake of heavy metals by vegetables irrigated using wastewater and the subsequent risks in Harare, Zimbabwe. Phys Chem Earth Part A/B/C. 2007;32(15-18):1399-405.

Monu A, Bala K, Shweta R, Anchal R, Barinder K, Neeraj M (2008) Heavy metal accumulation in vegetables irrigated with water from different sources.

Muchuweti M, Birkett JW, Chinyanga E, Zvauya R, Scrimshaw MD, Lester JN. Heavy metal content of vegetables irrigated with mixtures of wastewater and sewage sludge in Zimbabwe: implications for human health. Agric Ecosys Envir. 2006;112:41-8.

Obuobie E, Keraita B, Danso G, Amoah P, Cofie OO, Raschid-Sally L, Drechsel P (2006) Irrigated urban vegetable production in Ghana: characteristics, benefits and risks. IWMI, Accra at www.cityfarmer.org/GhanalrrigateVegis. html. Accessed 29 Jan 2017

Odai SN, Mensah E, Sipitey D, Ryo S, Awauah E. Heavy metals uptake by vegetables cultivated on urban waste dumpsites: case study of Kumasi, Ghana. Res J Environ Toxicol. 2008;2(2):92-9.

Prasad AS. Zinc deficiency: has been known of for 40 years but ignored by global health organisations. Br Med J. 2003;326(7386):409-10.

Rahman MA, Rahman MM, Reichman SM, Lim RP, Naidu R. Heavy metals in Australian grown and imported rice and vegetables on sale in Australia: health hazard. Ecotoxicol Environ Saf. 2014:100:53-60.

Sahito ATG, Kazi MA, Jakhrani GH, Kazi GQ, Shar MMA. Elemental investigation of Momordica charantia Linn. and Syziginm jambolana Linn. using atomic absorption spectrophotometer. Nucleus. 2002;39:49-54.

Sharma RK, Agrawal M, Marshall FM. Heavy metals contamination of soil and vegetables in suburban areas of Varanasi, India. Ecotox Envir Saf. 2007;66:258-66.

Siegel KR, Ali MK, Srinivasiah A, Nugent RA. Narayan KMV (2014) Do we produce enough fruits and vegetables to meet global health need? PLoS One. 2014:9:e104059.

Singh A, Sharma RK, Agrawal M, Marshall FM. Risk assessment of heavy metal toxicity through contaminated vegetables from wastewater irrigated areas in Varanasi, India. Trop Eco Iss. 2010;2:375-87.

Suruchi, Pankaj K. Assessment of heavy metal contamination in different vegetables grown in and around urban areas. Res J Environ Toxicol. 2011;5(3):162-79.

USEPA IRIS (2011) US Environmental Protection Agency's integrated risk information system. Environmental protection agency region I, Washington DC 20460. US EPA, 2012. http://www.epa.gov/iris/

Wang XL, Sato T, Xing BS, Tao S. Health risks of heavy metals to the general public in Tianjin, China via consumption of vegetables and fish. Sci Total Environ. 2005;350:28-37.

Weldegebriel Y, Chandravanshi BS, Wondimu T. Concentration levels of metals in vegetables grown in soils irrigated with river water in Addis Ababa, Ethiopia. Ecotox Envir Saf. 2012;77:57-63.

WHO / FAO. Expert committee on food additives. Cambridge: Cambridge University Press; 2007. p. 329-36.

Wongsasuluk P, Chotpantarat S, Siriwong W, Robson M. Heavy metal contamination and human health risk assessment in drinking water from shallow groundwater wells in an agricultural area in Ubon Ratchathani province, Thailand. Environ Geochem Health. 2014:36:169-82.

World Health Organization [WHO]. Evaluation of certain food additives and Contaminants. In: Sixty-First Report of the Joint FAO/WHO Expert Committee on Food Additives. Geneva: WHO; 2004. (WHO Technical Series, 922). 
Zheng N, Wang Q, Zhang X, Zheng D, Zhang Z, Zhang S. Population health risk due to dietary intake of heavy metals in the industrial area of Huludao city, China. Sci Total Environ. 2007;387:96-104.

Zhou H, Yang WT, Zhou X, Liu L, Gu JF, Wang WL, Zou JL, Tian T, Peng PQ, Liao $\mathrm{BH}$. Accumulation of heavy metals in vegetable species planted in contaminated soils and the health risk assessment. Int J Environ Res Public Health. 2016;13(289):1-12.

\section{Submit your manuscript to a SpringerOpen ${ }^{\circ}$} journal and benefit from:

- Convenient online submission

Rigorous peer review

- Open access: articles freely available online

- High visibility within the field

- Retaining the copyright to your article

Submit your next manuscript at $\boldsymbol{\sim}$ springeropen.com 